\title{
THE EFFECTIVENESS OF CONSTRAINT-INDUCED MOVEMENT THERAPY TO IMPROVE FUNCTIONAL ABILITY OF HANDS IN CHILDREN WITH UNILATERAL CEREBRAL PALSY: A META-ANALYSIS
}

\author{
Mutiana Agustin Sholikah'), Agus Kristiyanto²), Hanung Prasetya3) \\ 1)Masters Program in Public Health, Universitas Sebelas Maret \\ 2)Faculty of Sport Education, Universitas Sebelas Maret \\ ${ }^{3)}$ Health Polytechnics, Ministry of Health Surakarta
}

\begin{abstract}
Background: Constraint-induced movement therapy is an intervention designed to improve the upper-limb function. It is performed for individuals who experience functional loss in their impaired limb, such as stroke, cerebral palsy, traumatic brain injury, and multiple sclerosis. This study aimed to examine the effectiveness of constraintinduced movement therapy to improve functional ability of hands in children with unilateral cerebral palsy.

Subjects and Method: A systematic review and meta analysis study was conducted by collecting articles from Science Direct, AJOT, PubMed, Google Scholar, and Springer Link databases, with a range of publication years from 2010 to 2020. Keywords used "constraint-induced movement therapy", "hand function", "cerebral palsy", "constraintinduced movement therapy" AND "hand function", "constraint-induced movement therapy" AND "cerebral palsy". The inclusion criteria for this study were randomized control trial (RCT). Quantitative synthesis data was assessed using Review Manager 5.3 (RevMan 5.3) software.

Results: A total of 16 studies were included for meta-analysis. The results of meta analysis showed that CIMT improved hands functional ability in children with unilateral cerebral palsy $(\mathrm{SMD}=0.45 ; 95 \% \mathrm{CI}=0.11$ to $0.80 ; \mathrm{p}=0.01)$.

Conclusion: CIMT can improve hands functional ability in children with unilateral cerebral palsy.

Keywords: constraint-induced movement therapy, hands functional ability, unilateral cerabral palsy, meta analysis

\section{Correspondence:}

Mutiana Agustin Sholikah. Masters Program in Public Health, Universitas Sebelas Maret. Jl. Ir. Sutami 36A, Surakarta 57126, Central Java. Email: mutiana.ash@gmail.com. Mobile: 081215038686.
\end{abstract}

